\title{
PReS-FINAL-2206: Clinical experiences in patients with chronic recurrent multifocal osteomyelitis (CRMO)
}

\author{
B Sozeri ${ }^{1 *}$, B Yildiz², M Sezak ${ }^{3}$, M Argin ${ }^{4}$ \\ From 20th Pediatric Rheumatology European Society (PReS) Congress \\ Ljubljana, Slovenia. 25-29 September 2013
}

\begin{abstract}
Introduction
Chronic recurrent multifocal osteomyelitis (CRMO) is a form of chronic nonbacterial osteitis (CNO) characterized by one or more lytic bone lesions with no identifiable cause. (CRMO) is a rare (prevalence less than $1 /$ $1,000,000$ ) auto-inflammatory disorder, characterized by relapsing and remitting episodes of pain related to the presence of foci of sterile bone inflammation.
\end{abstract}

\section{Objectives}

We describe the clinical and laboratory features and treatment of a cohort of children with CRMO.

\section{Methods}

We retrospectively reviewed clinical, pathological and radiological data of children with CRMO at single tertiary pediatric center from Turkey. The diagnosis of CRMO was based on evidence of recurrent osteomyelitis with radiographic evidence of chronic osteomyelitis involving at least two sites in the absence of infectious cause in a child less than 14 years old.

\section{Results}

Six patients were assessed (34 females and 6 males) with a median age at diagnosis of 9,5 yrs (range 5-16). Median number of initial bony lesions was 2 at onset and 3.5 over disease course. Median time since diagnosis was $1.5 \mathrm{yrs}$ ) and median duration of active disease 0.7 yrs. Two patients had active disease at follow-up and continued to have pain. Two patients were treated with steroid, colchicine and sulphasalazine. Two patients had

${ }^{1}$ Pediatric Rheumatology, Ege University, Izmir, Turkey

Full list of author information is available at the end of the article methotrexate, 1 had colchicine while 1 had nonsteroidal anti-inflammatory drug.

\section{Conclusion}

This report indicates that CRMO may be overlooked in our community. Early diagnosis and treatment are required to avoid potential complications.

\section{Disclosure of interest}

None declared.

Authors' details

${ }^{1}$ Pediatric Rheumatology, Ege University, Izmir, Turkey. ${ }^{2}$ Pediatric Infectious Disease, Ege University, Izmir, Turkey. ${ }^{3}$ Pathology, Ege University, Izmir, Turkey. ${ }^{4}$ Radiology, Ege University, Izmir, Turkey.

Published: 5 December 2013

doi:10.1186/1546-0096-11-S2-P196

Cite this article as: Sozeri et al:: PReS-FINAL-2206: Clinical experiences in patients with chronic recurrent multifocal osteomyelitis (CRMO).

Pediatric Rheumatology 2013 11(Suppl 2):P196.

Submit your next manuscript to BioMed Central and take full advantage of:

- Convenient online submission

- Thorough peer review

- No space constraints or color figure charges

- Immediate publication on acceptance

- Inclusion in PubMed, CAS, Scopus and Google Scholar

- Research which is freely available for redistribution 